\title{
Bulgarian Cultural Identity as a Borderline One
}

\author{
YORDAN LJUCKANOV
}

\begin{abstract}
The article lists a number of cases of actual and possible application of the concept 'borderline' to characterise Bulgarian collective identity. Half of them date from the post-communist period and another half from the period between the two world wars. Through them I try to trace a theoretical intention that is sensitive to the teleology and ideology of modernisation (and especially to its Eurocentric bias). Thus I try to chart a set of self-identifications which could be opposed to what I consider the present mainstream in writing on collective identity issues in Bulgaria, to both its currents: the one claiming the status of avant-garde and the imperative of scholarly autonomy, and the other claiming classicality and compliance with national interests.

I view mainly $20^{\text {th }}-21^{\text {st }}$ c. expert works in cultural and art history, of both Bulgarian Middle Ages and modernity, but also some works of 'well-informed citizens' (or of experts outside their domain of expertise) who have felt obliged to share their prophetic visions in public, and even memoirs.

The article contains five chapters relating, correspondingly, to: (0) deliberation on the concept of borderlineness and its alternatives; (1) delineation of the conceptual tenets of the mainstream discourse of/on Bulgarian collective self-identification and self-instruction throughout the late $19^{\text {th }}$ - early $21^{\text {st }}$ centuries, and of what I believe are its major conceptual deficiencies (nation-centrism; Eurocentrism; cultural-historical monism; and linguo-centrism); (2) identification of late $20^{\text {th }}-$ early $21^{\text {st }}$ c. conceptualisations of Bulgarian identity which are relatively free from the above referred deficiencies and which recognise that identity's 'borderlineness'; (3) identification of similar conceptualisations from the interwar period (1920s1930s); (4) delineation of some epistemological assets of 'borderline awareness' and, esp., its compatibility with 'understanding-culture-as-plural', as well as of its fluctuation in scope and intensity within the Bulgarian $19^{\text {th }}-21^{\text {st }} \mathrm{c}$.

An analogical, and, inevitably, more complicated, exploration of the mental geographies and implicit Kulturphilosophies in works of Bulgarian artistic literature could be the subject of a subsequent paper.
\end{abstract}

Keywords: Bulgaria, teleology and ideology of modernisation, Eurocentrism, borderline identity, cultural plurality, plurality of oecumena, historiography of modernity, historiography of middle ages

0. What is 'borderline'? I would like to define this concept with regard to some neighbouring concepts: 'in-between', 'marginal', 'hybrid', 'composite', as well 
as 'liminal'. That which is 'composite' comprises many elements and maybe stays in a kind of centre of its own. 'Hybrid' (with or without referring to $\mathrm{H}$. Bhabha) suggests that the boundaries of the composites are penetrable and that some elements are maybe fusing. 'Marginal' suggests a border-by status or location, conceived from the standpoint of a centre. 'In-between' suggests a kind of a neutral zone between entities, not a border-line, but a border strip or that a border becomes a world of its own through expansion; yet there is a connotation of 'emptiness' with 'in-between-ness'. 'Borderline', thus, could be understood as 'still not or already not in-between'; 'doubly or multiply marginal but probably capable of achieving a balanced existence between centres'; 'potentially hybrid' (that is, potentially negotiating differences to melt them or at least make them interdependent); 'potentially composite' (that is, negotiating differences to retain them and to maintain a loose interdependence between them). ${ }^{1}$

'Borderline-ness' has something substantial in common with the condition of being incapable of (or probably with the choice of consciously retarding?) social maturing (or ageing), and the subsequent condition (or choice) of maintaining a "double existence", as analysed by Pierre Bourdieu on the example of Flaubert and his Frédéric (from Sentimental Education) (Bourdieu 1995: 12-13, 19-21, 26, 33). Thus 'liminal' occurs to be closest to 'borderline' among the aforementioned neighbouring concepts, but it is bit too much terminologically specific and hence obliging, to a tradition in anthropology; besides, it connotes more temporality (and less spatiality) than I would like to be connoted. The conditions I shall speak of are identifiable to captivity in, or deliberate hibernating of, a liminal, or middle, phase in a ritual of passage ${ }^{2}$. These conditions could be accessed from the perspective of cognitive literary theory if we count for a recent employment of the concept of 'hesitation's; and from the perspective of study of "transnational communities" and the

1 I prefer 'borderline' to 'frontier' and 'borderland' for its higher degree of generality; and prefer it to 'boundary' for its associability (esp. in the phrase "borderline identity") with psychology.

2 Cf. (Thomassen 2009: 6). Brief analytical histories of Arnold van Gennep's concept are available in (Thomassen 2009) and (Szakolczai 2009).

3 "The paradox lies in the circumstance that the possibility of choice is lost with the very act of choice". "[T] he individual wants to make his or her choice (s/he is forced to) but at the same time wants to preserve the possibility of [making] choice". "On the a-temporal axis of hesitation the agent experiences a state of, conditionally speaking, dispersion, of possessing - not as happy as in art - his or her multitude of 'I'-s" (Kolarov 2009: 78, 80, 85; here and below translation(s) mine, Y. L.). 
corresponding use of the concept of 'bi-focality'. The temporal aspect of 'border-line(ness)', if is to be relieved of psychologism, could be referred to through the concept of 'non-irreversibility's. Yet these concretising concepts ('hesitation', 'transnationality', 'bi-focality', '(non-ir)reversibility') lose the general sense of 'borderline'.

Are not all identities 'borderline', in some respect or another, on some scale or another? ${ }^{6}$ If yes, then what makes it reasonable to speak of some identities as of borderline and of others not? Maybe their self-awareness is a sufficient reason.

1.0. In the last century or more, Bulgarian scholars, thinkers and writers have expressed a notion of Bulgarian 'borderline-ness' repeatedly. Just like the notion of 'in-between-ness', it was less frequently expressed than the neighbouring notions of 'marginality' and 'hybridity'. The recurrent theme of all four neighbouring notions has been Bulgarian deficient 'European-ness' (if put in terms of 'marginality'), or Bulgarian belonging to both 'West' and 'East' (in terms of 'hybridity'), or Bulgarian condition between the 'West' and the 'East' (in terms of 'in-between-ness'), or, lastly, Bulgarian situation at the border between the 'West' and the 'East'. These notions, with the exception of the notion of 'marginality', gave birth to the metaphors of "crossroad" and "bridge", both shared by probably all Balkan national communities.

4 "Transnational communities commonly refer to migrant communities spanning two nations." (Kearney 1995: 559). "The [migrant-] sending states are insuring their own survival by contributing to the constitution of new bifocal subjects with dual citizenships and multiple political identities." (Guarnizo, Smith 1998: 8).

5 On the level of phenomena, this possibility was suggested through the differentiation between 'borderland societies' and 'transitional societies' made by Oleg Breskij (2005: 172-173). On the level of epistemology, non-irreversibility as (the) temporal correlate of borderline-ness was referred to by Michael Kearney (1995: 550) and Arpad Szakolczai (2009: 156) (see below, footnotes 17 and 18). Breskij launched, besides, the concept "субъектоспособность" ("capability-of-being-agent", or "agent-capacity"), which he defines as "the capability of a person or a corporation to produce the effect of a border". He views "agent-capacity" as the prerequisite for the emergence of borderland(s) (Пограничье). I would compare the lack of "agent-capacity" to the condition of being incapable of social maturing; and the presence of it to the condition of being able to take the choice to consciously retard one's own social maturing.

6 In asking this question, I claim that it is relevant to the reconsideration of the concept of 'liminality' offered by A. Szakolczai (2009: esp. 152-153, 157-158), as well as to the considerations against the "either-or" logic of classification that was typical in modern anthropology and for a "both-and-and" logic in (Kearney 1995: 558).

7 As indicated in: Georgieva 2003a: 49-50; Igov 1994. 
While thematising Bulgarian 'deficient European-ness' and 'EasternWestern-ness', Bulgarian self-identification discourse posed the following self-recommendations. ${ }^{8}$ First, Bulgarians should adopt the stance of conscious and even selective Europeanisation, in order to preserve the assets of the 'people's soul' and to stimulate and culturise its creativity. ${ }^{9}$ Second, Bulgarians should abandon their "Oriental" habits ${ }^{10}$ and foster their Slavonic sensibility ${ }^{11}$ and antiquity-rooted Balkan collective unconscious ${ }^{12}$ in order to enrich allhuman, in fact European, culture ${ }^{13}$. The 1920s-1930s seem to have produced the most influential articulations of these "musts" of, as I believe, chiefly selfdissociation and self-alienation; and this has been the main reference period for the explicit turn to issues of national cultural identification in the early 1990s, as witnessed by the contents of the still most influential anthology of such writings (Elenkov, Daskalov 1994).

1.1. I find these common "musts" of Bulgarian self-identification and selfinstruction theoretically deficient. They have been (affirmatively) overexposed and their deficiencies largely overseen in post-1989 Bulgarian scholarship. ${ }^{14}$ Before proceeding to self-identifications that have been less influential but, as I believe, are more heuristic, I shall point at the mainstream identification strategies' theoretical deficiencies. They are: first, non-questioning the presupposed meta-historicity of a nation; second, non-questioning the presupposed meta-historicity of a European culture, civilisation and identity; third, nonquestioning the presupposed existence of one single centre of civilisation-andculturisation in the world; and, fourth, overestimating language as a factor of collective identity. As a consequence, notion of levels of identity wider than nation and narrower than all-encompassing mankind was inhibited, with two exceptions: notions were forged of Slavonic mutuality and of Balkan nonvolent commonality. As another consequence, any cultural heritage which could not be associated with (Catholic-Protestant post-Renaissance) Europe has been naturalised, that is, made 'nature', in a dual sense: of 'living' and of 'inert nature'. Naturalised, that is: dissolved into a-historic essence and

8 In footnotes, I am leaving the names of some of the self-recommendations' most influential pronouncers (I wouldn't say 'authors').

9 Konstantin Gǔlǔbov; Gŭlǔbov 1994 [1926].

10 Bojan Penev; Penev 1994 [1923].

11 Gŭlǔbov 1994 (1926).

12 Najden Šejtanov; cf. below.

13 Janko Janev; cf. below.

14 In the realm of literary studies, a typical example of excellent command of sources combined with uncritical reproduction of their historical-cultural imperatives and theoretical-epistemological shortcomings is the book (Hristov 2009). 
a-historic substance. "Living" have been becoming the artefacts associable with the "national spirit" (and its life in a Europe of nations); and "dead" have been becoming the artefacts associable with alienable adversaries, neighbours and cohabitants (Byzantines, Ottomans, etc). ${ }^{15}$

A typical instance of postulating a borderline identity for the Bulgarians while maintaining a monist vision of culture and history is represented by the interwar period philosopher Janko Janev. In an essay titled "Изток ими ЗапаА” ("East or West"; 1933) he wrote that Bulgarians belong neither to the rational and lawful West nor to the intuitive and anarchic East but that, being "the most primary and virgin-elementary" people, have to venture self-cognition in order to "redeem paganism" and to say their own word to the world (Janev 1994 [1933]: 338-341). Typical for the Bulgarian debate on identity is the reduction of cultural-historical difference(s) to the gross dichotomy 'East vs. West' which only fuels cultural-historical monism whereby 'East' just plays the 'alter ego' of the sole 'ego' ever thinkable of.

Whereas Janev chose a 'tragic' form of monism, the $19^{\text {th }}$-century Bulgarian identity-makers had come to a 'comic' one.

Janev's claim ecstatically compensated for a deep identificational trauma which had been managed only temporarily. My contemporary Desislava Lilova traces what I believe is the same trauma back to the first half of the nineteenth century: Bulgarians possessed all formal assets to be considered Europeans (location, religion, race, language) but they themselves had deep doubts concerning their 'European-ness'; in other words, they could not decide whether to regard themselves as a civilised or as a barbaric nation - while unequivocally identifying civilisation with Europe (Lilova 2009). Drawing the conclusion that neither the bucolic utopia nor the reconstruction of a glorious past proved effective in creating "a sufficiently prestigious identity for the emerging nation", she goes on:

The alternative chosen by the elite was to make the definition of Europe more relative. This way the simultaneous belonging to both the 'barbarian' and the 'civilised' sphere [characteristic of the Bulgarians] was supposed to lose its status of anomaly and become a norm. ${ }^{16}$

15 One deeply symptomatic aspect of what can be called the 'annihilation of the potential dialogism of cultural accumulation' in Bulgarian culture was observed already in 1909 by the Russian archaeologist Fjodor Šmit...

16 Lilova 2009: par. 52 (I refer to the open access edition: http://books.openedition.org/ ceup/895?lang=en\#text). 
Cultural-historical monism's epistemological problematism obviously has too weak an appeal to be thematised by the modern researcher.

1.2. In the last two decades, the first of the aforementioned conceptual deficiencies, the non-questioning of nation's meta-historicity, has been challenged in scholarship. The mainstream debate - or at least tension, for some scholars claimed that there was not debate but parallel monologues - has focussed on the issue of the primordiality or, conversely, nineteenth-century constructedness of the nation. In works which can be designated as the works of a/the 'liberal' camp (why 'liberal', and neither 'conservative' nor 'leftist', I will discuss elsewhere), the complex tissue of overlapping and non-stable Balkan identities and loyalties was brought to the fore; and early modern history of the Bulgarian ethnic community has been growingly viewed within the Ottoman context. However, these developments had one major (if not single) theoretical concern: the de-mystification of the myth of the nation. They did not transcend the limits of the theories of development ${ }^{17}$ and, in particular, the teleologism of transitology ${ }^{18}$. "The teleology and ideology of modernization"19, freed from its Marxist-Leninist shape $\mathrm{e}^{20}$ and substantially theoretically enriched, survived the supposed death of "Big narratives" and flourished, in an underpronounced form and with an insubstantially changed mental geography. Of its 'three whales', one proved flexible: an epistemology of self-reflective or selfdelimitative logocentrism ${ }^{21}$ was adopted. The historicity of European-ness ${ }^{22}$,

17 "The image of unilineal time informing theories of development, i.e. time running from lesser to greater development, is logico-structurally consistent $[\ldots]$ with the binary space of centers and peripheries. [...] Non-teleological thinking has long prevailed in biology, a science that recognizes the randomness of evolutionary processes and the commonness of species extinction." (Kearney 1995: 550).

18 "While contemporary transitologists reject charges of teleology and don't indulge in philosophies of history, their perspective is still teleological in the sense that the 'solution' is given by the institutional tenets of democratic order" (Szakolczai 2009: 156).

19 As a core nerve of the "culture of enlightened modernity", "the teleology[-]and[-] ideology of modernization" implies "eurocentrism", "logocentrism", technological enthusiasm, and "unquestioned belief in the perpetual modernization of art" (Huyssen 1986: 195).

20 And unwilling to (re)adopt a nationalist.

21 That is, one aware of its limitations. In my opinion, among the Bulgarian works about Bulgarian identity, the work (Vačkova 2010) is especially promising. Yet it does not pertain to the liberal mainstream.

22 Gerald Delanty's Inventing Europe (1995) was issued in Bulgarian translation in 2004 but - if I am not overhasty - it received the attention only of students and scholars in European Studies. 
as well as the semi-unconscious Eurocentrism of both scholarship and "wellinformed-citizens" ${ }^{23}$ ' essayism (of either period - pre-communist, communist and post-communist), remained unquestioned ${ }^{24}$. It is only mentioned in passing when it comes to analysing the inadequateness of the periodisational concepts canonised by the nationalist imagination of Bulgarian scholarship on Bulgaria (as in Hranova 2011, 2: 183; Daskalov 2013: 47-62). The productiveness of the concept 'self-colonisation', adopted in the 1990s for the study of Bulgarian culture by Aleksandŭr Kjosev, remained underused. The daring attempt to investigate the modernisation of Bulgarian ethnic community in the $19^{\text {th }} \mathrm{c}$. as driven by Ottoman state policy (by Aleksandŭr Vezenkov; Vezenkov 2006) is, as far as I know, an exception, and only its national mythology deconstructing potential is utilised. The myth of inevitable and beneficial modernisation remained unquestioned too, being only attenuated, through the idea of 'domesticated modernisation' (Diana Miškova), or ephemerally brought into sight without further comment (as in Mishkova 2009: par. 30, 36-37). The self-centred discourse of description used the convenient label of "countermodern(ity)" for the possible manifestations of heterodoxy in the sources. ${ }^{25}$

Such an epistemological framework could hardly focalise the issue of 'borderline-ness'.

1.3. The dominant feature of what I see as 'high' academic mainstream ${ }^{26}$ in Bulgarian modernity studies is an essentialisation of 'European-ness' combined with problematisation of 'Bulgarian-ness'. I have chosen the reverse perspective. In sustaining 'Bulgarian-ness" nominal self-identity, I follow the works I employ as sources and I make use of a methodological asset produced

23 I borrow this concept from Alfred Schutz (Schutz 1976 (1946): 122).

${ }^{24}$ Yet there is the critical conclusion of Nikolaj Poppetrov (Poppetrov 2006: 175). It implies that viewing the processes in the $19^{\text {th }}$ century Balkans from a North-Atlantic perspective (in a "Europe-Atlantic-centrist" manner) - a tendency observed since the mid-1990s - could be ideologically motivated and exaggerating the subject matter.

25 I draw my conclusions shared in this paragraph from the following works: Balkanski 2001-2003; Occidentalism 2005; Miškova (ed.) 2006; K’osev (ed.) 2009; Konstantinova et al. 2011; Mishkova 2009; Detchev 2009; Lilova 2009; Hranova 2011; Daskalov 2013; Daskalov, Marinov (eds.) 2013; Daskalov, Mishkova 2013. Even Rumen Daskalov's Between the East and the West: Bulgarian Cultural Dilemmas, after its promising title, gives too little room for epistemological alternatives. It only suggests thinking of Bulgarian identity in terms of intercivilisational 'hybridity' while discussing the (reasons for the) ambivalent attitude (of contempt and half-hidden sympathy) of Bulgarians towards the most popular in Bulgaria Bulgarian literary character, Baj Ganjo (Daskalov 1998: 105).

26 The 'low' mainstream, associated by its opponents with the power of political heteronomy in the scholarly field, reproduces the nation-centrism of earlier scholarship. 
in post-colonial studies - "strategic essentialism" (Gayatri Spivak). If we agree that essentialisation of identities has to be suspended (for ethical reasons) or at least demystified (for gnoseological ones), then we should focus on Europeanisation, not on nationalisation, for the former still goes on, at least in Bulgaria, and the latter has long ago passed its momentum.

1.4. To summarise, modernity studies in post-communist Bulgaria have contributed little to question what I believe is a paradigm in thinking of collective identities: the conceptual tenets of Euro-centrism, culturalhistorical monism, nationalism and linguo-centrism ${ }^{27}$ in their interrelatedness. A work earlier than the aforementioned (Aretov 1995) seems freer from the ideology of modernisation, especially from its Eurocentric component, more sensitive to all four of the mentioned conceptual limitations, and closer to the issue of 'borderline-ness': it viewed the Bulgarian identification processes in the $19^{\text {th }} \mathrm{c}$. as a competition of identity versions.

As far as I am aware, medievalists have been more successful in expressing a notion of Bulgarian 'borderline-ness' while being less dependent on the aforementioned paradigm. Here, the typical instances of staying between worldorders (and not between civilisation and barbarity), language and religion, ethnic belonging and political loyalty surfaced in their rich phenomenology.

2.0. The key phrases which could point to these achievements are: "periphery as universe"; "circles of identity and Byzantinism"; "Romaic proto-nation"; "Israel and Judea"; "post-modern attitude to marriage in medieval Bulgaria after the adoption of Christianity"; "intercivilisational adaptation/convergence"; "agents of Russian despotism and petit bourgeois"; “are we one nation?”. I will attend to only some of them here.

2.1. "Periphery as universe" was introduced in 1998 by the then young scholar of early middle ages Cvetelin Stepanov. Stepanov meant that, till the mid-ninth century, the Bulgarian state, being a close neighbour of Byzantium, had belonged to a cultural world that is different from the Roman, Byzantine or Mediterranean - to the oecumene of the Eurasian steppe (Stepanov 1998), its core personification being the steppe 'emperor', namely, "c $(\mathrm{h})$ agan” (Stepanov 2005). Later Stepanov made a comparative examination of four steppe powers (Bulgars, Hazars, Tjurks and Ujgurs) in their conflict-and-interaction with the sedentary civilisations of the South (Byzantine, Arab, Iranic, Chinese)

27 The issue of linguo-centrism, through attending to the linguo-centric profile of Bulgarian nationalism, was accessed by Maria Todorova (reference in: Daskalov 1998: 216, footnote 69). Linguo-centric concerns of Balkan nationalisms are critically analysed in Section Two of Daskalov, Marinov, eds., 2013. 
and outlined the peculiarity of the Bulgarian case: Bulgars were the only ones to consistently use the script and, afterwards, adopt the faith of their main sedentary enemy (ibid. 86). And, he reminds us, Bulgars had invaded and populated a territory spanning along and across the boundary of East Roman oecumene - the lower Danube (ibid. 31 etc.). Early medieval Bulgarians ${ }^{28}$ exemplify for Stepanov a "borderline formation" (Stepanov 2008: 15). By 2008 Stepanov succeeded to show that after adopting Christianity, for more than three centuries, the Bulgarian state and elite, both lay and ecclesiastic, maintained a double identity, or a double legitimation perspective: of a Steppe power aspiring to be the Steppe Empire - and of a Christian kingdom aspiring to be a/the Christian Empire (ibid. 89-112), namely, to embody "the West" of the Byzantine, or Romaic, empire (an observation elaborated by Veselina Vačkova (see below), referred to by Stepanov). Meanwhile, having adopted recent views on quasi-national identities in the early Middle Ages (fluidity, heterogeneity, predominance of political loyalty over language, ethnicity and even religion ${ }^{29}$, rudimentary multilingualism) to the Bulgarian case (ibid. 24-30), he was able to claim the irrelevance of some traditional issues of Paleobulgarian studies: for example, till the $10^{\text {th }} \mathrm{c}$. Bulgarians had been neither sedentary nor nomadic, but could be both, according to the tasks allotted to one or another group by the government (ibid. 17-18); that is, borderline identity characterised that society on various levels.

2.2. The concept of "Romaic proto-nation" was introduced by the Belgian scholar of early Bulgarian modernity Raymond Detrez. According to Detrez, the emergence of the Romaic multi-ethnic nation, to comprise all Christian Orthodox subjects of the Ottoman Empire, had been under way until the 1830s, when the rise of Greek lay nationalism caused a ripple effect that destroyed it and lead to the formation of mono-ethnic nations (Detrez 2013). ${ }^{30}$ A notable representative of $19^{\text {th }}$ century Balkan poetry, Grigor Pŭrličev, was seen by Detrez as belonging basically to the Romaic proto-nation and deliberating between different identities: Romaic, Greek and Bulgarian (Detrez 2010).

2.3. The Old Testament historiosophic pair "Israel and Judea" was introduced in contemporary Bulgarian scholarship by the medievalist Veselina Vačkova in her book Imagined and Real Borders in Early Medieval

28 In standard accounts, a converging cohabitation of Bulgars, Slavs and autochthonous population of the Balkans.

29 Poly-confessionalism was consciously maintained by the rulers in the Eurasian Pax Nomadica (Stepanov 2005: 77).

30 While Slobodan Markovič (2013: 231) sees the beginning of the "collapse" in 1831, "with the ethniication of the Orthodox church in Serbia". 
Europe (Vačkova [2001]) in order to describe the peculiar relations between Christianised Bulgaria and Byzantium after the mid- $9^{\text {th }} \mathrm{c}$. Vačkova claims that the concept of "Byzantine commonwealth" (introduced by Dmitry Obolensky in the 1960s) is insufficient to explain them, for the ideological integration between the two states was significantly greater: the Bulgarian Tsardom viewed itself as an embodiment of the Western half of the Byzantine (Romaic, Roman) state, and the Byzantine elite was not far from accepting this claim. Besides, and peculiarly enough, Bulgarian Tsardom seems to have refrained from creating its own official historiography... Being a Bulgarian meant to be simultaneously an insider and an outsider, within and without Romaic identity. ${ }^{31}$

2.4. The idea of Christian-Muslim intercivilisational convergence on the Balkans since the late $14^{\text {th }} \mathrm{c}$. was advocated by Cvetana Georgieva. She sees the world as multi-civilisational but denies Samuel Huntington's vision of Islam's "bloody edge(s)" (Georgieva 2003a; 2003b). She speaks of mutual adaptation, especially on the level of neighbourhood, but points out the fragility of this equilibrium. Another scholar, Olga Todorova, attended to the rudiments of Christian-Muslim religious syncretism in the Ottoman period; and to the church organisation during most of that period, which could hardly sustain any kind of Bulgarian ethnic belonging except on lower levels (the case with a Serbian or Greek belonging being different) (Todorova 1997; compare with Markovich 2013: 229-230). Considering Georgieva's and Todorova's observations, one can conclude that to belong to the Bulgarian proto-national community in the Ottoman period (unlike belonging to the Greek, Serbian, Armenian or Vlakh) meant to be more prone to the possibility of changing identity, being on the verge of institutional non-representation.

3.0. Earlier conceptual oscillations around the notion of Bulgarian borderlineness are discernible in the period between the two world wars and could be associated with the following catch-phrases: "Paris or Jerusalem"; "Sasanian Iran on the lower Danube"; "Hellas and Byzantium"; "the expressionism of East-Christian mural art" (see Lyutskanov 2012: 189-190); "Bulgarian soul is tri-continental, or tri-maternal”; "Bulgarian Horde”; “Bulgarian' means 'mishmash(ed)'”.

3.1. "Paris or Jerusalem": in his memoirs, published in 1923, Mihail Madžarov witnessed a shift from a 'post-Byzantine' to a modern Euro-centric identity, and an oscillation between them.

31 Vačkova [2001]: 165-196. (A revised version of this book was published in French: Vatchkova 2006). 
Here they are, still fresh in my memory, the assiduousness and piety, with which the old Bulgarian men and women were going to Jerusalem, to bow to Lord's grave [...]. [Nowadays] Some are thirsty for Vienna, Paris, Berlin, whereas others for the East - for Tsarigrad [Constantinople], for Alexandria, for Jerusalem!.. Some want to see the Paris opera, whereas others - Golgotha and Mount Eleon. I do not know who are righter; but I would scorn neither the former nor the latter. (Madžarov 1923: 191)

Madžarov witnessed a shift from a Bulgarian ethnic belonging within the Romaic oecumene to a Bulgarian national identity within a world-wide Europe of nations. The fact that he could speak of both without renouncing any of them testifies to an intermediary, bivalent, or borderline stance.

3.2. "Hellas and Byzantium": since the mid-1920s, the archeologist and art historian Bogdan Filov applied his idea of two Europes (one having as its classical heritage Hellas and the other Byzantium (Filov 1926)) in his works on modern Bulgarian painting, claiming, in fact, its borderline stance. According to him, Bulgarian pictorial arts had to develop exploiting the aesthetic compatibility between the East-Christian artistic canon and European post-impressionism (Filov 1931: 426; Filov 1927: 109, 113). (More on the issue see in: Lyutskanov 2012.)

3.3. "Sasanian Iran on the lower Danube": in 1919 Filov had issued his History of Old Bulgarian Art (in English, French and German), claiming that lay monumental architecture of ninth-century Bulgaria had its parallels and probably models in Sasanian Iran (Filov 1919). In 1924 his book was published in Bulgarian. Later Filov appended his observations with the general vision of plurality of cultural circles, or of oecumena, in Eurasia; and of Bulgarian early medieval identity evolving/ sliding on the verge between three of them: the Nomadic, the Iranian, and the Roman or Mediterranean (Filov 1929). ${ }^{32}$

3.4. "Bulgarian soul is tri-continental, or tri-maternal", or Euro-AfroAsian: this is the final, 1940, formula of the ethnologist, sexologist and visionary Najden Šejtanov in what seems to be a fanciful appropriation and extension of Spengler's morphology of culture and Russian eurasianism (Šejtanov [1940]: 6-7). Šejtanov supported his claim with a brave interpretation of Bulgarian folklore and Balkan toponymy. Systematically conflating the subject matter of a series of discourses (geology, biology, social sciences, humanities, folklore and fiction), he demonstrated the core-ness of borderline-ness.

32 I shall focus on this issue in a subsequent publication. 
Bulgarian Cultural Identity as a Borderline One

4. Bulgarian cultural identity has been conceived as borderline, in-between or composite by a number of Bulgarian thinkers throughout the $20^{\text {th }}$ century. This notion has been crucial for developing an understanding that cultural identity is plural. It seems to me that the latter understanding is an indispensable prerequisite to maintain what can be called 'border(line) thinking', a mode of extracting/constructing cultural sense which is the most apt in borderline cultural regions like the Balkan (or Balkan-Caucasian-Anatolian, or Black Sea) one.

To reflectively exist on a border means to understand identity as potentially plural, potentially hybrid and potentially forgeable. This borderline awareness has, in my opinion, a correlate from the realm of artistic styles: the aptitude to co-employ a number of other styles to form a compound whole which Jacob Burckhardt called "spatial” style (Burckhardt [1900]: 582-583).

In order to understand how 'understanding-culture-as-plural' can work in the case of Bulgarian self-representations, we have to relate the phenomenology of borderline awareness to three moments (two historical and one theoretical).

First, the modern notion and, then, awareness of plurality could only come to existence when 'modernisation' became able of critical self-reflection, or of recognising its limitations (I refer neither to Anthony Giddens nor to Ulrich Beck here). That which had been conceived as 'nature' subject to culturisation, became to be conceived as a different 'culture', with a centre of reason of its own. In the Bulgarian case, this awareness emerged in the memoir, historiography and culture-philosophic discourses of the 1920s; but remained marginal.

Second, the mentioned notion has been reinforced by the 2000s, when awareness was attained about the more or less universal span of cultural identity's plurality; plurality is no more conceived as close to exceptional peculiarity of Bulgarian cultural identity.

Third, in order to maintain a stance that would not turn our 'ideographical' mode of thinking into a 'nomothetical', we should abstain from thinking that all cultural 'pluralities' are alike. That is, I maintain that the pluralities 'in/of' French, Latvian and Bulgarian identities are different not only because the components within each are different. The adequate 'calibration' of our view is the main issue here: we have to count for the different levels that expose a collective identity of a nation (sub-national, (inter)national, super-national). We have to reinforce our awareness of cultural regions and of 'civilisations'; we ought to understand that 'mankind' and 'world history' are no less constructs 
LJUCKANOV

than 'Europe'33 and nations. Borders that undermine a nation's unity run not only along social class or state borders, not only along the borders of minorities' enclaves and not only along the borders between continents. ${ }^{34}$

My account can impart the impression that 'borderline-ness' of Bulgarian identity, from being a matter of conception by academic and nonacademic intellectuals either, has become a realm of academic study only; that 'borderline-ness' of Bulgarian identity has come to be seen as past; that twentieth century Bulgarian 'high' culture failed to forge 'borderline', 'bivalent' or 'spatial' intellectual and artistic styles. Indeed, Bulgarian painting was alone in its fluctuations between European modernisms and avant-guards and Byzantine tradition. But recently an intellectually empathic academic reconstruction of Byzantine philosophy was performed (by Georgi Kapriev); and the preoccupation with Balkan studies, though one which is still either Eurocentric or Balkan-centric, grows. This adds to my feeble hope.

\author{
Yordan Ljuckanov \\ yljuckanov@gmail.com \\ Institute for Literature, BAS / Институт за митература, БАН \\ Shipchenski Prokhod blvd. 52, block 17, fl. 7 / \\ бум. Шипченски прохоА 52, блок 17, ет. 7 \\ Sofia 1113 / София 1113 \\ BULGARIA
}

\title{
References
}

Aretov, N. 1995. Bŭlgarskoto Vŭzraždane i Evropa. Sofija: Kralica Mab. = Аретов, H. 1995. Българското Възраждане и Европа. София: Крамица Маб.

Balkanski. 2001-2003. Balkanski identičnosti. Č. I - IV. Sofija: Institut za izsledvane na integracijata. $=$ Балкански. 2001-2003. Балкански идентичности. Ч. I- IV. София: Институт за изследване на интеграцията.

\footnotetext{
33 'Europe' is not only 'heterogeneous', as it is commonly maintained, but 'made'; yet, symptomatically, D. Mishkova evades the latter predicate in her article "In quest of Balkan Occidentalism” (Miškova 2006: 238-239).

34 From this standpoint, Bulgarian borderlineness shares commonalities with the borderlineness of such national identifications as the Turkish (hesitating between Turkism/Turanism, Osmanism and Islamism; see Bibina), Serbian of the $18^{\text {th }}-19^{\text {th }} \mathrm{c}$. (emerging in-between the Ottoman and the Habsburg worlds; see Markovich 2013: 229), Spanish (deliberating between Europeanism and Hispanidad as super-national sociotopes).
} 
Bibina, J. Balkanskite identičnosti prez prizmata na tjurljuka. = Бибина, Й. Бацканските идентичности през призмата на тюрлюка. - http://balkansbg.eu/ bg/content/b-identichnosti/487-tyurklyuka.html. [English summary: http:// balkansbg.eu/en/content/balkan-identities/430-balkan-identities-through-theoptics-of-turkishness.html] (14.01.15).

Bourdieu, P. 1995. The Rules of Art. Transl. by Susan Emanuel. Stanford: Stanford University Press.

Breskij, O. 2005. Geografija Vostočnoj Evropy: prostranstvo Pogranič ja. - Perekrestki, [5], 1-2, 168-186. = Бреский, О. 2005. География Восточной Европы: пространство Пограничья. - Перекрестки, [5], 1-2, 168-186.

Burckhardt, J. [1900]. Kultur und Kunst der Renaissance in Italien. (Ungekürzte Textausgaben). Berlin: Deutsche Buch-Gemainschaft G.M.B.H.

Daskalov, R. 1998. Meždu Iztoka i Zapada: Bülgarski kulturni dilemi. Sofija: LIK. = Ааскалов, Р. 1998. Между Изтока и Запада: Български културни дилеми. София: $\Lambda$ ИК.

Daskalov, R. 2013. Kak se misli bŭlgarskoto vŭzraždane: 10 godini po-kŭsno. [2 $2^{\text {nd }}$ ed.] Sofija: Prosveta. $=$ Ааскалов, Р. 2013. Как се мисли българското възраждане: 10 години по-късно. [2 ${ }^{\text {nd }}$ ed.] София: Просвета.

Daskalov, R., Miškova, D. 2013. "Forms without Substance”: Debates on the Transfer of Western Models to the Balkans. - Daskalov, Mishkova, eds., Entangled Histories of the Balkans V. 2: Transfers of Political Ideologies and Institutions, Brill, 1-96.

Daskalov, R., Marinov, T., eds. 2013. Entangled Histories of the Balkans V. 1.: National Ideologies and Language Policies, Brill.

Detchev, S. 2009. "Race”, Science and Politics in Fin-de-Siècle Bulgaria. - D. Mishkova, ed., We, the People (Politics of National Peculiarity in Southeastern Europe). Budapest: CEU Press, 237-269.

Detrez, R. 2010. The Temptation of National Identity: The Case of Grigor Purlichev. - E. Agoston-Nikolova, ed., Shoreless Brigdes: South East European Writing in Diaspora. Amsterdam: Rodopi, 53-63.

Detrez, R. 2013. Pre-national Identities on the Balkans. - R. Daskalov, T. Marinov, eds., Entangled Histories of the Balkans V. 1.: National Ideologies and language Policies. Boston: Brill, 13-64.

Elenkov, I., Daskalov, R., eds. 1994. Zašto sme takiva? (V tŭrsene na bŭlgarskata kulturna identičnost). [Antologija]. Sofija: Prosveta. = Еленков, И., Ааскалов, P., eds. 1994. Защу сме такива? (В тьрсене на българската културна идентичност). [Антология]. София: Просвета.

Filov, B. 1919. Die altbulgarische Kunst. Bern: Haupt.

Filov, B. 1926. Vizantija i Elada. - Bŭlgarska misŭl, 2, 32-41 \& 125-135. = Филов, Б. 1926. Византия и Елада. - Българска мисъл, 2, 32-41 \& 125-135.

Filov, В. 1927. Starobŭlgarskite freski. - Zlatorog, 8, 108-113. = Фимов, Б. 1927. Старобъмгарските фрески. - 3латорог, 8, 108-113.

Filov, B. 1929. Proizhoždenieto na starobŭlgarskoto izkustvo. - Zlatorog, 10, 294300. = Филов, Б. 1929. ПроизхожАението на старобъцгарското изкуство. -3ramopoz, 10, 294-300. 


\section{LJUCKANOV}

Filov, B. 1931. Pŭrvite desetiletija na sŭvremennoto bŭlgarsko izkustvo. - Zlatorog, 12, 425-433. = Фимов, Б. 1931. Първите Аесетиметия на съвременното бъмгарско изкуство. - 3латорог, 12, 425-433.

Georgieva, C. 2003a. Transformaciite na edin sblŭsŭk na civilizacii - hristijanstvoto i isljama na Balkanite. - E. Radušev, S. Fetvadžieva, eds., Balkanski identičnosti, III. Sofija: Institut za izsledvane na integracijata, 49-76. = Георгиева, Ц. 2003а. Трансформациите на еАин сблъсък на цивилизации - християнството и исляма на Балканите. - Е. Радушев, С. Фетваджиева, eds., Балкански идентичности, III. София: Институт за изследване на интеграцията, 49-76.

Georgieva, C. 2003b. Hristijani i mjusjulmani v bŭlgarskoto prostranstvo. - M. Tahir, K. Aleksova, eds., Balkanski identičnosti, IV, Sofija: Institut za izsledvane na integracijata, 2003, 7-29. = Георгиева, Ц. 2003b. Християни и мюсюлмани в бъмгарското пространство. - М. Тахир, К. Алексова, eds., Балкански идентичности, IV, София: Институт за изслеАване на интеграцията, 2003, 7-29.

Guarnizo, L. E., Smith, M. P. 1998 [2006]. The Locations of Transnationalism. - M. P. Smith, L. E. Guarnizo, eds., Transnationalism from Below. New Brunswick, New Jersey: Transactions Publishing [ $6^{\text {th }}$ printing, 2006], 3-34.

Gǔlǔbov, K. 1994 [1926]. Našite kulturni zadači. - R. Daskalov, I. Elenkov, eds., Zašto sme takiva?, 210-212. = Гъмъбов, К. 1994 [1926]. Нашите културни задачи. - Р. Ааскалов, И. Еленков, еds., Защо сме такива?, 210-212.

Hranova, A. 2011. Istoriografija i literatura, I-II. Sofija: Prosveta, 2011. = Хранова, А. 2011. Историография и литература, I-II. София: Просвета, 2011.

Hristov, I. 2009. Krŭgŭt "Strelec" i idejataza rodnoto. Sofija: Karina-Mariana Todorova. = Христов, И. 2009. Крбгът “Стрелеи” и идеята за родното. София: КаринаМариана Тодорова.

Huyssen, A. 1986. Mapping the Postmodern (1984). - Huyssen, After the Great Divide: Modernism, Mass Culture, Postmodernism. Bloomington and Indianapolis: Indiana UP, 1986, 179-221.

Igov, S. 1994. Homo Balcanicus: krŭstopŭtnijat čovek. - Literaturno-estetičeski procesi na Balkanite. Sofija: BAN, Institut po balkanistika, 46-57. = Игов, С. 1994. Ноmo Balcanicus: кръстопътният човек. - Аитературно-естетически процеси на Балканите. София: БАН, Институт по балканистика, 46-57.

Janev, Ja. 1994 [1933]. Iztok ili Zapad. - R. Daskalov, I. Elenkov, eds., Zašto sme takiva?, 337-341. = Янев, Я. 1994 [1933]. Изток ими ЗапаА. - Р. Ааскалов, И. Еленков, eds., Защо сме такива?, 337-341.

Kearney, M. 1995. The Local and the Global: The Anthropology of Globalization and Transnationalism. - Annual Review of Anthropology, 24, 547-565.

Kolarov, R. 2009. Povtorenie i sŭtvorenie: poetika na avtotekstualnostta. Sofija: Prosveta. = Коларов, Р. 2009. Повторение и сътворение: поетика на автотекстуалността. София: Просвета.

Konstantinova, Ju. et al., eds. 2011. Balkanite: modernizacija, identičnosti, idei (Sbornikv čest na prof. Nadja Danova). Sofija: Institut za balkanistika s Centŭr po trakologija. = Константинова, Ю. et al., eds. 2011. Балканите: модернизация, 
Bulgarian Cultural Identity as a Borderline One

идентичности, идеи (Сборниквчест на проф. Надя Аанова). София: Институт за балканистика с Център по тракология.

K’osev, A., ed. 2009. Podvižnite Balkani: izsledvanija na proekta NEXUS (2000-2003).

Sofija: Prosveta. $=$ Кьосев, А., еd. 2009. Подвижните Балкани: изследвания на проекта NEXUS (2000-2003). София: Просвета.

Lilova, D. 2009. Barbarians, Civilized People and the Bulgarians: Definition of Identity in the Textbooks and the Press. - D. Mishkova, ed., We, the People, 179-206.

Lyutskanov, Y. 2012. Notes on how the avant-garde could recall non-modernity on a European periphery. - H. Veivo, ed., Transferts, appropriations et fonctions de l'avant-garde dans l'Europe intermédiaire et du nord. Paris: L'Harmattan, 185-199.

Madžarov, M. 1923. Dnešna Palestinja. - Duhovna kultura, [4], 18-19, 191-201. = МаАжаров, М. 1923. Анешна Паместиня. - Ауховна култура, [4], 18-19, 191-201.

Markovich, S. 2013. Patterns of National Identity Development among the Balkan Orthodox Christians during the Nineteenth Century. - Balcanica, 44, 209-254.

Miškova, D., ed. 2006. Balkanskijat XIX vek: Drugi pročiti. Sofija: CAI; Riva. = Мишкова, А., ed. 2006. Балканският XIX век: Аруги прочити. София: ЦАИ; Рива.

Miškova, D. 2006. V tŭrsene na balkanskija oksidentalizŭm. - D. Miškova, ed., Balkanskijat XIX vek: Drugi pročiti. Sofija: CAI; Riva, 235-272. = Мишкова, A. 2006. В търсене на балканския оксидентализъм. - А. Мишкова, ed., Балканският ХІХ век: Аруги прочити. София: ЦАИ; Рива, 235-272.

Mishkova, D. 2009. Introduction: Towards a Framework in Studying the Politics of National Peculiarity in the $19^{\text {th }}$ Century. - D. Mishkova, ed., We, the People, 1-43. Occidentalism 2005 = Occidentalism, or the "images" that the East projects of the West (Conference proceedings). [Sofia]: Bulgarian Society for the $18^{\text {th }}$ Century Studies; Centre for Advance Studies, available at: http://www.bulgc18.com/ occidentalism/index_en.htm (14.01.15).

Penev, B. 1994 [1923]. Prevraštenijata na Baj Ganja. - R. Daskalov, I. Elenkov, eds., Zašto sme takiva?, 121-130. = Пенев, Б. 1994 [1923]. Превращенията на Бай Ганя. - Р. Ааскалов, И. Еленков, еds., Защу сме такива?, 121-130.

Poppetrov, N. 2006. Bǔlgarskoto vŭzraždane: beležki kŭm edin (ne)vǔzmožen debat. - D. Miškova, ed., Balkanskijat XIX vek, 164-181. = Поппетров, Н. 2006. Бъмгарското възраждане: бележки към еАин (не)възможен Аебат. А. Мишкова, еd., Балканският ХІХ век, 164-181.

Stepanov, T. 1998. Periphery as Universe. - Byzantinoslavica, 59, 2, 247-254.

Stepanov, C. 2005. Bŭlgarite i stepnata imperija prez rannoto srednovekovie: problemŭt za Drugite. Sofija: Gutenberg. = Степанов, Ц. 2005. Българите и степната империя през ранното средновековие: проблемьт за Аругите. София: Гутенберг.

Stepanov, C. 2008. Istorija vs. psevdonauka: drevnobŭlgarski etjudi. Sofija: Siela. = Степанов, Ц. 2008. История vs. псевдонаука: древнобългарски етюди. София: Сиема. 
LJUCKANOV

Szakolczai, A. 2009. Liminality and Experience: Structuring transitory situations and transformative events. - International Political Anthropology, 2, no. 1 (special issue: On Liminality), 141-172.

Šejtanov, N. [1940]. Balkano-bŭlgarski titanizŭm. Sofija: Bŭlgarska kniga. = Шейтанов, Н. [1940]. Балкано-български титанизбм. София: Бъмгарска книга.

Thomassen, B. 2009. The Uses and Meanings of Liminality. - International Political Anthropology, 2, no. 1, 5-28.

Todorova, O. 1997. Bŭlgarskata cŭrkva prez XV-XVIII vek. Sofija: AI Marin Drinov. = Тодорова, О. 1997. Българската църква през XV-XVIII век. София: АИ Марин Аринов.

Vačkova, V. [2001]. Vŭobražaemi i realni granici v rannosrednovekovna Evropa (III-IX v.). Sofija: Universitetsko izdatelstvo. = Вачкова, В. [2001]. Въображаеми и реални граници в ранносредновековна Европа (III-IX в.). София: Университетско изАателство.

Vačkova, V.2010. Belite poleta v bŭlgarskata kulturna pamet. Sofija: Voenno izdatelstvo. = Вачкова, В. 2010. Белите полета в българската културна памет. София: Военно изаателство.

Vatchkova, V. 2006. Les images et les réalités des frontières en Europe médiévale (III-XI siècle). Sofia: Gutenberg.

Vezenkov, A. 2006. Očevidno samo na prŭv pogled: "Bǔlgarskoto vǔzraždane" kato otdelna epoha. - D. Miškova, ed., Balkanskijat XIX vek: Drugi pročiti. Sofija: CAI; Riva, 82-127. = Везенков, А. 2006. Очевидно само на пръв поглеА: “Бъцгарското възражАане” като отАелна епоха. - А. Мишкова, ed., Балканският ХІХ век: Аруги прочити. София: ЦАИ; Рива, 82-127. 